\title{
Low-dose peripheral blood stem cell graft after high-dose chemotherapy - an evaluation of hematopoietic reconstitution
}

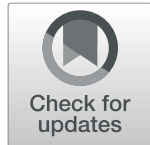

Sandra Sauer ${ }^{1 *}$, Petra Pavel ${ }^{2}$, Anita Schmitt ${ }^{1}$, Martin Cremer ${ }^{1}$, Mark Kriegsmann $^{3}$, Thomas Bruckner ${ }^{4}$, Karin Jordan $^{1}$, Patrick Wuchter ${ }^{5}$, Carsten Müller-Tidow ${ }^{1}$ and Katharina Kriegsmann ${ }^{1}$

\begin{abstract}
Background: High-dose (HD) chemotherapy followed by autologous blood stem-cell transplantation (ASCT) is the standard treatment for multiple myeloma (MM) patients. However, the collection of sufficient peripheral blood stem cell (PBSC) grafts can be challenging, and the question arises whether reinfusion of low-dose grafts will lead to a hematopoietic recovery.

Methods: The hematopoietic recovery of 148 MM patients who underwent HD melphalan chemotherapy and received PBSC transplants with varying CD34+ cells doses $\left(3-4 \times 10^{6}[n=86], 2-2.5 \times 10^{6}[n=53],<2 \times 10^{6}[n=9]\right.$ per $\mathrm{kg}$ body weight [bw]) was analyzed in this retrospective single-center study.

Results: All patients reached hematopoietic reconstitution, even those who received $<2 \times 10^{6} \mathrm{CD} 34+$ cells $/ \mathrm{kg}$ bw. 62 (42\%) patients received granulocyte-colony-stimulating factor (G-CSF). The median duration to leukocyte recovery $\geq 1.0 \times 10^{9} / \mathrm{L}$ was 12 days in every group. The median duration to platelet recovery $\geq 20 \times 10^{9} / \mathrm{L}$ was 11,13 and 13 days, respectively. In the multivariate analysis, a low number of reinfused CD34+ cells was associated with prolonged time until leukocyte reconstitution ( $p=0.010$, HR 0.607) and platelet recovery $(p<0.001$, HR 0.438). GCSF support significantly accelerated leukocyte ( $p<0.001$, HR 16.742) but not platelet reconstitution.

Conclusion: In conclusion, reinfusion of low- and even very-low-dose PBSC grafts leads to sufficient hematopoietic reconstitution. No severe adverse events were observed during or after HD chemotherapy and ASCT in the analyzed cohort. While the impact of CD34+ cell dose is marginal, G-CSF significantly accelerates the leukocyte recovery.
\end{abstract}

Keywords: Peripheral blood stem cells, Insufficient graft, Autologous stem-cell transplantation, Multiple myeloma

\section{Background}

High-dose (HD) chemotherapy followed by autologous blood stem-cell transplantation (ASCT) is the standard of care and a highly effective therapy for multiple myeloma (MM) [1, 2]. Although HD/ASCT was initially established as a single therapy for first-line treatment of

\footnotetext{
* Correspondence: sandra.sauer@med.uni-heidelberg.de 'Department of Hematology, Oncology and Rheumatology, Heidelberg University, Im Neuenheimer Feld 410, 69120 Heidelberg, Germany Full list of author information is available at the end of the article
}

MM [3, 4], subsequent randomized trials demonstrated an overall survival benefit with tandem ASCT, particularly in patients who did not achieve at least partial remission (PR) [5, 6]. Later studies showed that salvage HD/ASCT may represent an effective treatment option for MM patients who relapse after a sustained remission that lasted longer than 1 year after a prior ASCT [7-9]. The indication for up to three HD/ASCTs might occur over the course of MM treatment.

(c) The Author(s). 2020 Open Access This article is licensed under a Creative Commons Attribution 4.0 International License, which permits use, sharing, adaptation, distribution and reproduction in any medium or format, as long as you give appropriate credit to the original author(s) and the source, provide a link to the Creative Commons licence, and indicate if changes were made. The images or other third party material in this article are included in the article's Creative Commons licence, unless indicated otherwise in a credit line to the material. If material is not included in the article's Creative Commons licence and your intended use is not permitted by statutory regulation or exceeds the permitted use, you will need to obtain permission directly from the copyright holder. To view a copy of this licence, visit http://creativecommons.org/licenses/by/4.0/ The Creative Commons Public Domain Dedication waiver (http://creativecommons.org/publicdomain/zero/1.0/) applies to the data made available in this article, unless otherwise stated in a credit line to the data. 
As a prerequisite for ASCT, hematopoietic stem cells must be available. Peripheral blood stem cells (PBSCs) have become the most widely used source for hematopoietic stem cells in the setting of HD/ASCT treatment for MM [10, 11]. PBSCs (i.e., CD34+ cells) must be mobilized either with mobilization chemotherapy and granulocyte-colony-stimulating factor (G-CSF) or with G-CSF alone and subsequently collected by leukapheresis [12]. Usually, a successful collection of up to three sufficient PBSC grafts $\left(>2.0-2.5 \times 10^{6}\right.$ CD34+ cells $/ \mathrm{kg}$ body weight [bw] per graft) from MM patients can be achieved when the PBSC collection is performed after induction treatment i.e., prior to the first HD/ ASCT [13, 14]. However, many factors, such as higher age, previous extensive chemotherapy, and treatment with melphalan or radiation therapy, might be associated with poor PBSC mobilization, despite the use of plerixafor, which results in borderline sufficient $\left(<2.0-2.5 \times 10^{6}\right.$ CD34+ cells/kg bw) grafts [15-19]. In this case, transplant centers frequently face the question of whether reinfusion of grafts with marginal PBSC numbers will lead to a delay in hematopoietic recovery after HD chemotherapy and subsequently cause any complications or even severe adverse events due to prolonged neutropenia. This issue is of great relevance, particularly to MM patients who might significantly benefit from HD/ ASCT treatment in terms of MM disease control.

The aim of this study was to demonstrate that hematopoietic reconstitution is not significantly delayed, even if a low $\left(2.0-2.5 \times 10^{6} / \mathrm{kg}\right.$ bw $)$ or a very low $(<2.0 \times$ $10^{6} / \mathrm{kg}$ bw) number of PBSCs is reinfused during ASCT. Moreover, the question of whether the number of reinfused PBSCs affects the duration until achieving hematopoietic recovery will be answered.

\section{Methods}

\section{Patient selection and data matching}

A retrospective single-center analysis of MM patients who underwent HD melphalan chemotherapy and ASCT between January 2016 and August 2018 at our university hospital was performed. The patients were grouped according to the number of reinfused CD34+ cells at ASCT, as follows: $3-4 \times 10^{6} \mathrm{CD} 34+$ cells $/ \mathrm{kg}$ bw (group 1), $2-2.5 \times 10^{6} \mathrm{CD} 34+$ cells $/ \mathrm{kg}$ bw (group 2), $<2 \times 10^{6}$ CD34+ cells/kg bw (group 3). Group 1 reflects the median reference value of reinfused CD34+ cells at our institution, as previously reported [20, 21]. To achieve homogenization between groups 1 and 2, only patients who received one round of HD/ASCT therapy in their course of treatment were included. As there were only few patients in group 3, the second or third HD/ASCT was also considered in this group. Patients in group 3 received in median $1,89 \times 10^{6}$ (range 1,74 to $1,99 \times 10^{6}$ ) CD34+ cells $/ \mathrm{kg}$ bw. The clinical parameters (sex and age), ISS stage and Salmon and Durie stage at first diagnosis, type of monoclonal protein, modality of induction and mobilization therapy, remission status before and after each ASCT, number of transplanted CD34+ cells and hematological reconstitution data were collected retrospectively. The retrospective data analysis was approved by the Ethics Committee of the Medical Faculty, Heidelberg University.

\section{Multiple myeloma induction therapy}

MM treatment was initiated according to the SLiMCRAB criteria [22]. The standard induction treatment was 4 cycles of VCD (bortezomib $1.3 \mathrm{mg} / \mathrm{m}^{2}$, s.c., days 1 , 4, 8, 11; cyclophosphamide $1000 \mathrm{mg} / \mathrm{m}^{2}$, i.v., day 1 ; dexamethasone $40 \mathrm{mg}$, p.o., days 1, 2, 4, 5, 8, 9, 11, 12). Sixtythree patients received either 4 cycles of VRD (bortezomib $1.3 \mathrm{mg} / \mathrm{m}^{2}$, s.c., days $1,4,8,11$; lenalidomide $25 \mathrm{mg}$, p.o., days 1-14; dexamethasone $20 \mathrm{mg}$, p.o., days 1, 2, 4, $5,8,9,11,12,15$ optional $)$ or elotuzumab $(10 \mathrm{mg} / \mathrm{kg}$, i.v., days 1, 8, 15 in cycle 1 and 2; days 1, 11 in cycles 3 and 4) in combination with VRD as induction therapy. The remission status was assessed according to international myeloma working group response criteria [23].

\section{PBSC mobilization, collection and quality assessment}

PBSC mobilization was performed as previously described [20]. In summary, CAD (cyclophosphamide $1000 \mathrm{mg} / \mathrm{m}^{2}$, i.v., day 1 ; doxorubicin $15 \mathrm{mg} / \mathrm{m}^{2}$, i.v., days 1-4; dexamethasone $40 \mathrm{mg}$, p.o., days 1-4) was administered as a standard chemomobilization regimen. Three patients received cyclophosphamide $\left(1000 \mathrm{mg} / \mathrm{m}^{2} /\right.$ day, i.v., days 1-2) only. G-CSF $(5-10 \mu \mathrm{g} / \mathrm{kg}$ per day) was injected subcutaneously starting 5 days after mobilization chemotherapy and was administered until the end of PBSC collection. The number of CD34+ cells was determined by flow cytometry as described previously when peripheral blood leukocytes reached $\geq 5.0 \times 10^{3} / \mu \mathrm{l}[24]$. When the peripheral blood CD34+ cell count reached $\geq 20 / \mu$ l, leukapheresis (LP) was initiated. Stem cell collection was performed at the Spectra Optia apheresis machine (MNC program, software version 7.2 and 11.2). In the case of poor mobilization (i.e. $<20 \mathrm{CD}^{+} 4^{+}$cells $/ \mu \mathrm{L}$ under G-CSF stimulation or less than one third of the individual collection goal reached with the first leukapheresis session), pre-emptive or rescue plerixafor $(240 \mu \mathrm{g} / \mathrm{kg})$ was administered subcutaneously 9 to $12 \mathrm{~h}$ before the LP session. The minimum number of CD34+ cells for one transplant was defined as $\geq 2.0 \times 10^{6} / \mathrm{kg}$ bw at our institution, with the goal of collecting sufficient CD34+ cells for three transplants to ensure the option for a tandem transplantation or anHD melphalan and ASCT in case of relapse.

PBSCs processing and storage was in accordance with the German Medical Council and further scientific 
society's guidelines [25-27]. The PBSCs were stored for $24-48 \mathrm{~h}$ at 2 to $6^{\circ} \mathrm{C}$ until cryopreservation. The maximum nucleated cell (NC) concentration was $2 \times 10^{8}$ / $\mathrm{mL}$. After storage, the PBSC products were centrifuged and diluted with autologous plasma or resuspension medium (Plasmalyte A, Baxter, Unterschleissheim, Germany or Composol PS, Fresenius Kabi, Bad Homburg, Germany) and CryoSure-D dimethyl sulfoxide (DMSO, WAK-Chemie Medical, Steinbach, Germany). The target NC concentration was $\leq 5 \times 10^{8} / \mathrm{mL}$ and the total volume was $100 \mathrm{~mL}$ per bag. The final product included 10\% DMSO and was stored in Cryocyte bags (Baxter, Unterschleissheim, Germany or CryoMACS Freezing bags (Miltenyi, Idarobrstein, Germany). The PBSCs controlled-rate freezed (Biofreeze BV50, Consarctic, Schoellkrippen, Germany). The storage conditions were vapor-phase nitrogen and a temperature of <$140^{\circ} \mathrm{C}$. Upon transplantation, the cryopreserved bags were thawed at the bedside (Plasmatherm device, Barkey $\mathrm{GmbH} \& \mathrm{Co} . \mathrm{KG}$, Leopoldshoehe, Germany) at $37^{\circ} \mathrm{C}$. PBSCs were reinfused without previous washing within a maximum of $10 \mathrm{~min}$ of thawing using standard transfusion filters.

For quality assessment in accordance with the Stem Cell Enumeration Committee Guidelines of the International Society for Cell Transplantation, a an enumeration of NC and red blood cells, flow cytometry-based CD34+ cell quantification and volume determination were performed directly after PBSC collection [28]. A microbiological culture sample was obtained shortly before freezing. $\mathrm{NC}$ enumeration and $\mathrm{NC}$ viability measurements were performed in the PBSC aliquots $48 \mathrm{~h}$ after freezing and in samples that were stored for a duration $>36$ months. Overall, the following target values were defined for the end product (one PBSC transplant): $\mathrm{NC}$ concentration $\leq 5 \times 10^{8} / \mathrm{mL}, \mathrm{CD} 34+$ cell number $\geq$ $2 \times 10^{6} / \mathrm{kg}$ bw, a total volume of $100 \mathrm{~mL}$ per portion (up to 3 portions possible), no microbial growth, and a minimum NC viability of $50 \%$. Viability testing was valid for a maximum duration of 3 years.

\section{HD chemotherapy and ASCT}

All patients received melphalan $\left(100 \mathrm{mg} / \mathrm{m}^{2}\right.$, day -3 and day -2 , one-hour infusion) as high dose chemotherapy conditioningregimen. When creatinine clearance was $\leq 40 \mathrm{~mL} / \mathrm{min}$, the melphalan dosage was reduced by $50 \%$. An supportive medication regimen (dexamethasone $4 \mathrm{mg}$ p.o., day - 3 ; dexamethasone $2 \mathrm{mg}$ p.o., day 2 to day -1 , granisetron hydrochloride $2 \mathrm{mg}$ p.o., days 3 to day 0 , aprepitant $125 \mathrm{mg}$ p.o., day -3 , aprepitant 80 $\mathrm{mg}$ p.o., day -2 to day 0 ) was used for prevention of chemotherapy-induced nausea and vomiting [29]. A minimum of $2.0 \times 10^{6} \mathrm{C} 34+$ cells $/ \mathrm{kg}$ bw was reinfused using supportive therapy (500 $\mathrm{mg}$ acetaminophen p.o., 2 mg clemastine i.v., $10 \mathrm{mg}$ dihydrocodeine p.o.) on day 0 . As antiviral and antibiotic prophylaxis, patients received daily acyclovir $2 \times 400 \mathrm{mg}$ p.o. for 6 months, dayli ciprofloxacin $2 \times 500 \mathrm{mg}$ p.o. until hematological reconstitution, and cotrimoxazole $960 \mathrm{mg}$ p.o. three times a week for 3 months.

Our analysis comprises MM patients who underwent HD melphalan chemotherapy and ASCT between January 2016 and August 2018 at our university hospital. At our institution antibiotic prophylaxis with ciprofloxacin or cotrimoxazole twice a day was stopped in January 2017 due to increasing prevalence of multidrug resistant bacteria and replaced by G-CSF support after ASCT and Pneumocystis jirovecii pneumonia prophylaxis with cotrimoxazole thrice a week in March 2017. Therefore, in a subset of patients, G-CSF $(10 \mu \mathrm{g} / \mathrm{kg}$ bw per day) was administered starting from day 1 after ASCT until leukocyte recovery $\geq 1.0 \times 10^{9} / \mathrm{L}$.

\section{Assessment of hematological reconstitution}

After HD melphalan and ASCT, blood counts were performed dayli until leukocyte and platelet engraftment. Leukocyte engraftment was defined by a leukocyte count of $\geq 1.0 \times 10^{9} / \mathrm{L}$. Days in aplasia were defined as number of days with leukocytes $<1.0 \times 10^{9} / \mathrm{L}$. Neutrophil recovery was defined as the first of three consecutive days with neutrophils $\geq 0.5 \times 10^{9} / \mathrm{L}$. Platelet engraftment was defined as the first day of three consecutive values with platelet count $\geq 20 \times 10^{9} / \mathrm{L}$ without previous platelet transfusion for 7 days. We also calculated days until the platelet count $\geq 50 \times 10^{9} / \mathrm{L}$ as a variable for platelet engraftment, as the platelet count in some patients did not drop below $20 \times 10^{9} / \mathrm{L}$ or was not assessable due to platelet transfusion.

\section{Statistical analysis}

Statistical analysis was performed for the overall cohort and with regard to the number of reinfused CD34+ cells at ASCT. Due to the low number of patients in group 3, comparative statistics were performed between groups 1 and 2.

Descriptive statistics and comparisons between groups were performed by $\mathrm{R}$ studio (Version 1.1.383, RStudio, Inc.). Data are presented as absolute numbers and percentages and as medians and ranges. To compare categorical variables, the chi-square test was used. To identify differences between group means, comparisons between the two groups were performed with unpaired two-tailed Student's t-tests. The leukocyte, neutrophil and platelet recovery over time was calculated and plotted using Kaplan-Meier survival analysis. To calculate differences between the engraftment curves, a log-rank test was applied. The Cox proportional hazard model 
and the Breslow method were used for multivariate analysis. A $p<0.05$ was considered statistically significant.

\section{Results}

\section{Patient characteristics}

Data from 148 MM patients (87 male and 61 female) were analyzed. The median age at first diagnosis was 60 (41-72) years. International Staging System (ISS) stage I was found in 85 (57\%), ISS II in 25 (17\%), and ISS III in $31(21 \%)$ patients, in 7 patients ISS stage was not available. In patients with stage I and II disease $(n=11)$ according to the Salmon-Durie classification at first diagnosis, the indications for treatment initiation were based on the SLiM CRAB criteria and were abnormal kappa/lambda ratio/involved free light-chain level 100 $\mathrm{mg} / \mathrm{L}$ or higher $(n=8)$, bone marrow infiltration by plasma cells above $60 \%(n=1)$ and more than one focal lesion on magnetic resonance imaging $(n=2)$. The majority of patients $(n=70,47 \%)$ received VCD for induction treatment. Patients who were treated within the GMMG HD6 trial received either VRD $(n=30,20 \%)$ or elotuzumab-VRD ( $n=33,22 \%)$. The median number of induction treatment cycles was 4 (range 2-8). Nearly all patients $(n=143,97 \%)$ received CAD/G-CSF for PBSC mobilization. To achieve the PBSC collection goal, plerixafor administration was necessary in 2 (1\%) patients.

Table 1 presents patient characteristics at first diagnosis and induction and mobilization therapy with regard to the overall cohort and subgroups defined by the number of transplanted CD34+ cells.

\section{Characterization of HD/ASCT treatment according to the number of transplanted CD34+ cells}

To answer the clinically important question whether the number of transplanted CD34+ cells impacts hematopoietic reconstitution after HD/ASCT therapy and achieving homogenization, we focused on the first HD/ASCT therapy in the patient's course of treatment (groups 1 and 2). Fifty-three of the patients had a low dose graft $\left(2-2.5 \times 10^{6} \mathrm{CD} 34+\right.$ cells $\left./ \mathrm{kg}\right)$ and three of the patients had a very low dose graft $\left(<2 \times 10^{6} \mathrm{CD} 34+\right.$ cells $/ \mathrm{kg}$ ) for their first autologous transplant. However, reinfusion of $<2 \times 10^{6} \mathrm{CD} 34+$ cells $/ \mathrm{kg}$ at ASCT was a rare event. Therefore, patients undergoing second or third HD/ASCT treatment were included in group 3.

In the overall cohort, 88 (59\%) patients had complete remission $(\mathrm{CR})$, near complete remission $(\mathrm{nCR})$ or very good partial remission (VGPR) prior to HD/ASCT treatment. The median age at HD/ASCT therapy was 61 (range 41-75) years. Melphalan dose modifications were performed for $2(1 \%)$ patients. After HD/ASCT therapy, the number of patients who achieved CR, nCR or VGPR increased to 111 (74\%).
Other than the number of reinfused CD34+ cells (given by the definition of the groups), no statistically significant differences were found between groups 1 (3$4 \times 10^{6} \mathrm{CD} 34+$ cells $\left./ \mathrm{kg} \mathrm{bw}\right)$ and $2\left(2-2.5 \times 10^{6} \mathrm{CD} 34+\right.$ cells/kg bw) with regard to HD/ASCT treatment. Details of the HD/ASCT therapy for the overall cohort and the subgroups are summarized in Table 2.

\section{Hematopoietic reconstitution according to the number of transplanted CD34+ cells}

All patients reached hematopoietic reconstitution after HD/ASCT treatment, even those who received $<2 \times 10^{6}$ CD34+ cells $/ \mathrm{kg}$ bw (group 3). Since the number of patients in group $3\left(<2 \times 10^{6} \mathrm{CD} 34+\right.$ cells $/ \mathrm{kg}$ bw $)$ was very low $(n=9)$, statistical comparisons were performed between groups $1\left(3-4 \times 10^{6} \mathrm{CD} 34+\right.$ cells/kg bw) and 2 $\left(2-2.5 \times 10^{6} \mathrm{CD} 34+\right.$ cells $/ \mathrm{kg}$ bw) only (Table 3$)$.

The median time to achieve leukocytes $\geq 1.0 \times 10^{9} / \mathrm{L}$ after PBSC reinfusion was 12 days in all groups and ranged between 9 and 23 days, 10-24 days and 9-16 days in groups 1, 2 and 3, respectively. No statistically significant difference in time to leukocyte engraftment was observed between groups 1 and 2 (Fig. 1 A, $p=0.393$ ). The median duration of aplasia was 9 (range 4-19), 8 (range 5-20) and 9 (5-13) days for groups 1, 2 and 3, respectively, and no statistically significant differences were found between groups 1 and 2 .

Neutrophil reconstitution was evaluated in a small proportion of patients $\left(\mathrm{n}_{\text {group1 }}=17, \mathrm{n}_{\text {group } 2}=23\right.$, $\mathrm{n}_{\text {group } 3}=2$ ) only. The median time from ASCT to neutrophil recovery was 14 (range 9-19), 13 (range 10-18) and 13 (11-14) days for groups 1, 2 and 3, respectively.

The median duration to platelet recovery $\geq 20 \times 10^{9} / \mathrm{L}$ was 11 (range 9-16), 13 (range 10-21) and 13 (9-19) days for groups 1,2 and 3 , respectively. Patients who received a high number of CD34+ cells $\left(3-4 \times 10^{6} \mathrm{CD} 34+\right.$ cells/kg bw, group 1) showed a faster platelet $\geq 20 \times 10^{9} /$ $\mathrm{L}$ recovery than patients who received a low number of reinfused CD34+ cells $\left(2-2.5 \times 10^{6} \mathrm{CD} 34+\right.$ cells $/ \mathrm{kg}$ bw, group 2) (Fig. 1 B, $p<0.001$ ).

Data on platelet recovery $\geq 50 \times 10^{9} / \mathrm{L}$ were available in a smaller proportion of patients $\left(\mathrm{n}_{\text {group } 1}=55, \mathrm{n}_{\text {group2 }}=\right.$ $23, \mathrm{n}_{\text {group } 3}=3$ ) only. The median duration to platelet recovery $\geq 50 \times 10^{9} / \mathrm{L}$ was 14 (range $10-18$ ), 14 (range 1322) and 15 (13-18) days for groups 1,2 and 3, respectively. Similar to platelet reconstitution $\geq 20 \times 10^{9} / \mathrm{L}$, the log-rank comparison revealed a significantly faster platelet recovery $\geq 50 \times 10^{9} / \mathrm{L}$ in patients who received a high number of CD34+ cells than patients who received a low number of CD34+ cells $(p=0.001)$.

Overall, the univariate analysis revealed an association between a higher number of reinfused CD34+ cells and fast platelet recovery after ASCT. But, this effect was not evident for leukocyte reconstitution. As a proportion of 
Table 1 Patient characteristics and previous therapy regimens

\begin{tabular}{|c|c|c|c|c|c|}
\hline Parameter & $\begin{array}{l}\text { Overall } \\
\text { cohort }\end{array}$ & $\begin{array}{l}\text { Group1 }\left(3-4 \times 10^{6} \text { CD34+ }\right. \\
\text { cells/kg bw) }\end{array}$ & $\begin{array}{l}\text { Group } 2\left(2-2.5 \times 10^{6} \text { CD34+ }\right. \\
\text { cells } / \mathrm{kg} \mathrm{bw})\end{array}$ & $\begin{array}{l}\boldsymbol{P} \text { value Group } \\
1 \text { vs. } 2\end{array}$ & $\begin{array}{l}\text { Group } 3 \\
\left(<2 \times 10^{6} \mathrm{CD} 34+\text { cells } / \mathrm{kg} \mathrm{bw}\right)\end{array}$ \\
\hline Patient number, $\mathrm{n}$ & 148 & 86 & 53 & / & 9 \\
\hline Sex, n (\%) & & & & 0.030 & \\
\hline Male & $87(59)$ & $44(51)$ & $37(70)$ & & $6(67)$ \\
\hline Female & $61(41)$ & $42(49)$ & $16(30)$ & & $3(33)$ \\
\hline \multicolumn{6}{|l|}{ Diagnosis of $\mathrm{MM}, \mathrm{n}(\%)$} \\
\hline $\begin{array}{l}\text { Median age at first } \\
\text { diagnosis, years (range) }\end{array}$ & $\begin{array}{l}60(41- \\
72)\end{array}$ & $60(44-72)$ & $61(41-71)$ & 0.854 & $60(46-72)$ \\
\hline Stage at first diagnosis & & & & / & \\
\hline । & $7(5)$ & $4(5)$ & $3(6)$ & & $9(100)$ \\
\hline$\|$ & $4(3)$ & $3(3)$ & $1(2)$ & & $0(0)$ \\
\hline III & $136(92)$ & $79(92)$ & $48(91)$ & & $0(0)$ \\
\hline NA & $1(1)$ & $0(0)$ & $1(2)$ & & $0(0)$ \\
\hline A & $129(87)$ & $78(91)$ & $44(83)$ & / & $7(78)$ \\
\hline B & $18(12)$ & $8(9)$ & $8(15)$ & & $2(22)$ \\
\hline NA & $1(1)$ & $0(0)$ & $1(2)$ & & $0(0)$ \\
\hline Heavy chain type & & & & $0.767^{\mathrm{a}}$ & \\
\hline $\lg G$ & $95(64)$ & $56(65)$ & $37(70)$ & & $2(22)$ \\
\hline $\lg A$ & $29(20)$ & $17(20)$ & $8(15)$ & & $4(44)$ \\
\hline $\lg D$ & $1(1)$ & $1(1)$ & $0(0)$ & & $0(0)$ \\
\hline Light chain only & $23(16)$ & $12(14)$ & $8(15)$ & & $3(33)$ \\
\hline Light chain type & & & & 0.452 & \\
\hline kappa & $96(65)$ & $53(62)$ & $36(68)$ & & $7(78)$ \\
\hline lambda & $52(35)$ & $33(38)$ & $17(32)$ & & $2(22)$ \\
\hline \multicolumn{6}{|l|}{ Induction therapy, $\mathrm{n}(\%)$} \\
\hline $\begin{array}{l}\text { Median number of cycles } \\
\text { (range) }\end{array}$ & $4(2-8)$ & $4(2-6)$ & $4(3-8)$ & & $4(3-5)$ \\
\hline VCD & $70(47)$ & $39(45)$ & $28(53)$ & $0.297^{b}$ & $3(33)$ \\
\hline VRD & $30(20)$ & $22(26)$ & $8(15)$ & & $0(0)$ \\
\hline Elotuzumab-VRd & $33(22)$ & $22(26)$ & $10(19)$ & & $1(11)$ \\
\hline Other/modifications & $15(10)$ & $3(3)$ & $7(13)$ & & $5(56)$ \\
\hline Mobilization therapy, n (\%) & & & & / & \\
\hline $1 \times C A D$ & $143(97)$ & $85(99)$ & $50(94)$ & & $8(89)$ \\
\hline Other & $5(3)$ & $1(1)$ & $3(6)$ & & $1(11)$ \\
\hline \multicolumn{6}{|c|}{ Remission prior PBSC collection, $\mathrm{n}(\%)$} \\
\hline$n C R$ & $25(17)$ & $19(22)$ & $5(9)$ & $0.041^{c}$ & $1(11)$ \\
\hline VGPR & $52(35)$ & $34(40)$ & $17(32)$ & & $1(11)$ \\
\hline PR & $54(36)$ & $25(29)$ & $25(47)$ & & $4(44)$ \\
\hline$M R$ & $8(5)$ & $5(6)$ & $2(4)$ & & $1(11)$ \\
\hline SD & $1(1)$ & $1(1)$ & $0(0)$ & & $0(0)$ \\
\hline NA & $8(5)$ & $2(2)$ & $4(8)$ & & $2(22)$ \\
\hline
\end{tabular}

${ }^{\mathrm{a}} \mathrm{gD}$ not included

${ }^{\mathrm{b}} \mathrm{Other} /$ modifications not included

${ }^{\prime} \mathrm{nCR} / \mathrm{VGPR}$ versus $\mathrm{PR} / \mathrm{MR} / \mathrm{SD}$

$C A D$ cyclophosphamide, doxorubicin, dexamethasone; MM multiple myeloma; MR minimal response; NA not available; $n C R$ near complete remission; PBSC

peripheral blood stem cells; $P R$ partial remission; $S D$ stable disease; VCD bortezomib, VGPR very good partial remission; $V R D(d)$ vincristine, lenalidomide (revlimid),

dexamethasone; cyclophosphamide, dexamethasone; vs., versus 
Table 2 High-dose chemotherapy/ASCT

\begin{tabular}{|c|c|c|c|c|c|}
\hline Parameter & $\begin{array}{l}\text { Overall } \\
\text { cohort }\end{array}$ & $\begin{array}{l}\text { Group } 1\left(3-4 \times 10^{6} \text { CD34+ }\right. \\
\text { cells } / \mathrm{kg} \mathrm{bw})\end{array}$ & $\begin{array}{l}\text { Group } 2\left(2-2.5 \times 10^{6} \text { CD34+ }\right. \\
\text { cells } / \mathrm{kg} \mathrm{bw})\end{array}$ & $\begin{array}{l}\boldsymbol{P} \text { value Group } \\
1 \text { vs. } 2\end{array}$ & $\begin{array}{l}\text { Group } 3\left(<2 \times 10^{6} \text { CD34+ }\right. \\
\text { cells } / \mathrm{kg} \mathrm{bw})\end{array}$ \\
\hline ASCTs analyzed, $n$ & 148 & 86 & 53 & / & 9 \\
\hline Sequential ABSCTs, n (\%) & & & & / & \\
\hline First & $142(96)$ & $86(100)$ & $53(100)$ & & $3(33)$ \\
\hline Second & $5(3)$ & $0(0)$ & $0(0)$ & & $5(56)$ \\
\hline Third & $1(1)$ & $0(0)$ & $0(0)$ & & $1(11)$ \\
\hline Remission pre ABSCT, n (\%) & & & & $0.168^{\mathrm{a}}$ & \\
\hline$C R$ & $2(1)$ & $2(2)$ & $0(0)$ & & $0(0)$ \\
\hline $\mathrm{nCR}$ & $38(26)$ & $28(33)$ & $9(17)$ & & $1(11)$ \\
\hline VGPR & $48(32)$ & $26(30)$ & $21(40)$ & & $1(11)$ \\
\hline PR & $45(30)$ & $21(24)$ & $18(34)$ & & $6(67)$ \\
\hline MR & $4(3)$ & $3(3)$ & $1(2)$ & & $0(0)$ \\
\hline SD & $1(1)$ & $0(0)$ & $1(2)$ & & $0(0)$ \\
\hline PD & $6(4)$ & $2(2)$ & $3(6)$ & & $1(11)$ \\
\hline NA & $4(3)$ & $4(5)$ & $0(0)$ & & $0(0)$ \\
\hline $\begin{array}{l}\text { Median age at ASCT, years } \\
\text { (range) }\end{array}$ & $\begin{array}{l}61(41- \\
75)\end{array}$ & $61(44-73)$ & $62(41-72)$ & 0.886 & $60(50-75)$ \\
\hline \multicolumn{6}{|l|}{ Transplanted PBSCs } \\
\hline $\begin{array}{l}\text { Median transplanted CD34+ cells } \\
\times 10^{6} / \mathrm{kg} \text { (range) }\end{array}$ & $\begin{array}{l}3.2(1.7- \\
4.0)\end{array}$ & $3.6(3.0-4.0)$ & $2.3(2.0-2.5)$ & $<0.001$ & $1.9(1.7-1.99)$ \\
\hline Median vitality, \% (range) & $\begin{array}{l}79(53- \\
93)\end{array}$ & $76(53-93)$ & $81(58-93)$ & 0.012 & $80(66-93)$ \\
\hline HD chemotherapy, n (\%) & & & & / & \\
\hline Melphalan $2 \times 100 \mathrm{mg} / \mathrm{m}^{2}$ & $146(99)$ & $85(99)$ & $53(100)$ & & $8(89)$ \\
\hline Dose reduction & $2(1)$ & $1(1)$ & $0(0)$ & & $1(11)$ \\
\hline Remission post ASCT, $\mathrm{n}(\%)$ & & & & $0.316^{\mathrm{b}}$ & \\
\hline$C R$ & $15(10)$ & $11(13)$ & $4(8)$ & & $0(0)$ \\
\hline $\mathrm{nCR}$ & $42(28)$ & $30(35)$ & $11(21)$ & & $1(11)$ \\
\hline VGPR & $54(36)$ & $27(31)$ & $22(42)$ & & $5(56)$ \\
\hline$P R$ & $25(17)$ & $11(13)$ & $12(23)$ & & $2(22)$ \\
\hline$M R$ & $5(3)$ & $3(3)$ & $2(4)$ & & $0(0)$ \\
\hline SD & $1(1)$ & $1(1)$ & $0(0)$ & & $0(0)$ \\
\hline PD & $2(1)$ & $2(2)$ & $0(0)$ & & $0(0)$ \\
\hline NA & $4(3)$ & $1(1)$ & $2(4)$ & & $1(11)$ \\
\hline
\end{tabular}

${ }^{a / b} C R / n C R / V G P R$ versus $P R / M R / S D / P D$.

$A S C T$ autologous blood stem cell transplantation; $C R$ complete remission; $H D$ high-dose; $M R$ minimal response; $N A$ not available; $n C R$ near complete remission; $P D$ progressive disease; $P R$ partial remission; $S D$ stable disease; VGPR very good partial remission; vs., versus

the analyzed patients $(n=62,42 \%)$ received G-CSF support after ASCT, we hypothesized that G-CSF administration might significantly accelerate leukocyte reconstitution and mask the influence of the number of reinfused CD34+ cells. A subgroup analysis based on the number of reinfused CD34+ cells and G-CSF support status showed that the median time to leukocyte reconstitution was significantly shortened by G-CSF support from 14 to 10 days in the $3-4 \times 10^{6} \mathrm{CD} 34+$ cells $/ \mathrm{kg}$ bw group and from 14 to 11 days in the $2-2.5 \times 10^{6} \mathrm{CD} 34+$ cells/kg bw group ( $p<0.001$, respectively; Fig. 2 A). GCSF administration significantly shortened the time to platelet recovery $\geq 20 \times 10^{9} / \mathrm{L}$ in the $2-2.5 \times 10^{6} \mathrm{CD} 34+$ cells $/ \mathrm{kg}$ bw group $(p=0.020)$ but not in the $3-4 \times 10^{6}$ CD34+ cells/kg bw group ( $p=0.200$, Fig. 2 B). No statistically significant differences in time to platelet recovery $\geq 50 \times 10^{9} / \mathrm{L}$ were observed with regard to G-CSF administration either in the $3-4 \times 10^{6} \mathrm{CD} 34+$ cells $/ \mathrm{kg}$ bw group $(p=0.800)$ or in the $2-2.5 \times 10^{6} \mathrm{CD} 34+$ cells $/ \mathrm{kg}$ bw group $(\mathrm{p}=0.200)$. 
Table 3 Hematopoietic reconstitution after high-dose chemotherapy/ASCT by number of transplanted CD34+ cells

\begin{tabular}{|c|c|c|c|c|c|}
\hline Parameter & $\begin{array}{l}\text { Overall } \\
\text { cohort }\end{array}$ & $\begin{array}{l}\text { Group } 1\left(3-4 \times 10^{6} \text { CD34+ }\right. \\
\text { cells } / \mathrm{kg} \text { bw) }\end{array}$ & $\begin{array}{l}\text { Group } 2\left(2-2.5 \times 10^{6} \text { CD34+ }\right. \\
\text { cells } / \mathrm{kg} \text { bw) }\end{array}$ & $\begin{array}{l}\boldsymbol{P} \text { value Group } \\
1 \text { vs. } 2\end{array}$ & $\begin{array}{l}\text { Group } 3\left(<2 \times 10^{6} \text { CD34+ }\right. \\
\text { cells } / \mathrm{kg} \text { bw) }\end{array}$ \\
\hline ASCTs analyzed, $n$ & 148 & 86 & 53 & & 9 \\
\hline G-CSF support, n (\%) & & & & 0.271 & \\
\hline Yes & $62(42)$ & $34(40)$ & $26(49)$ & & $2(22)$ \\
\hline No & $86(58)$ & $52(60)$ & $27(51)$ & & 7 (78) \\
\hline $\begin{array}{l}\text { Leukocyte } \\
\text { reconstitution }\end{array}$ & & & & 0.393 & \\
\hline $\mathrm{n}$ available & 144 & 82 & 53 & & 9 \\
\hline $\begin{array}{l}\text { Days to } L \geq 1.0 \times 10^{9} \text { / } \\
L\end{array}$ & $12(9-24)$ & $12(9-23)$ & $12(10-24)$ & & $12(9-16)$ \\
\hline $\begin{array}{l}\text { Neutrophil } \\
\text { reconstitution }\end{array}$ & & & & / & \\
\hline $\mathrm{n}$ available & 42 & 17 & 23 & & 2 \\
\hline $\begin{array}{l}\text { Days to } N \geq 0.5 \times \\
10^{\prime} / L\end{array}$ & $14(9-19)$ & $14(9-19)$ & $13(10-18)$ & & $13(11-14)$ \\
\hline Aplasia & & & & 0.513 & \\
\hline n available & 116 & 62 & 46 & & 8 \\
\hline Days in aplasia & $9(4-20)$ & $9(4-19)$ & $8(5-20)$ & & $9(5-13)$ \\
\hline $\begin{array}{l}\text { Platelet } \\
\text { reconstitution }\end{array}$ & & & & $<0.001$ & \\
\hline $\mathrm{n}$ available & 144 & 85 & 51 & & 8 \\
\hline $\begin{array}{l}\text { Days to platelets } \\
\geq 20 \times 10^{9} / \mathrm{L}\end{array}$ & $12(9-21)$ & $11(9-16)$ & $13(10-21)$ & & $13(9-19)$ \\
\hline n available & 81 & 55 & 23 & 0.001 & 3 \\
\hline $\begin{array}{l}\text { Days to platelets } \\
\geq 50 \times 10^{9} / \mathrm{L}\end{array}$ & $14(10-22)$ & $14(10-18)$ & $14(13-22)$ & & $15(13-18)$ \\
\hline
\end{tabular}

If not otherwise indicated, the data are presented as the median (range)

ASCT autologous blood stem cell transplantation; G-CSF granulocyte-colony stimulating factor; $L$ leukocytes, $N A$ not available; $N$ neutrophils; vs., versus

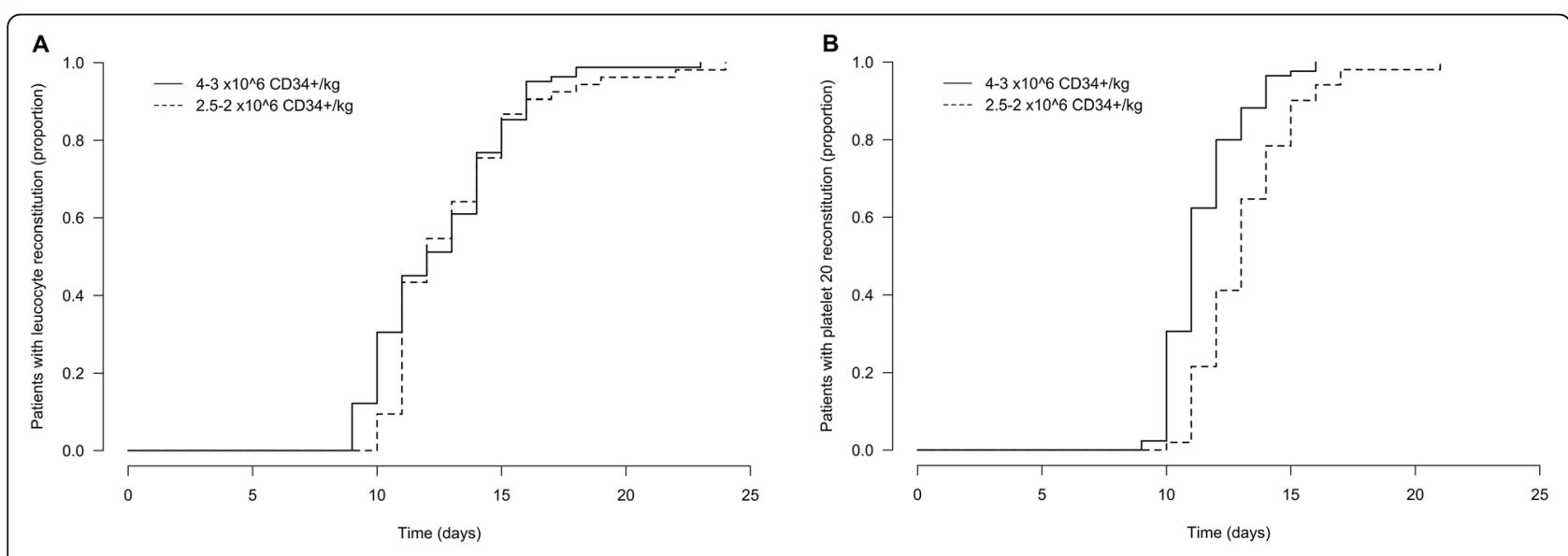

Fig. 1 Hematopoietic reconstitution after HD/ASCT by the number of reinfused CD34+ cells. The relative number of patients with leukocyte recovery $\geq 1.0 \times 10^{9} / \mathrm{L}(\mathbf{a})$ and platelet recovery $\geq 20 \times 10^{9} / \mathrm{L}(\mathbf{b})$ is shown. The results are grouped according to the number of reinfused $\mathrm{CD} 34+$ cells ( $3-4$ versus $2-2.5 \times 10^{6}$ CD34+ cells $/ \mathrm{kg}$ bw) 

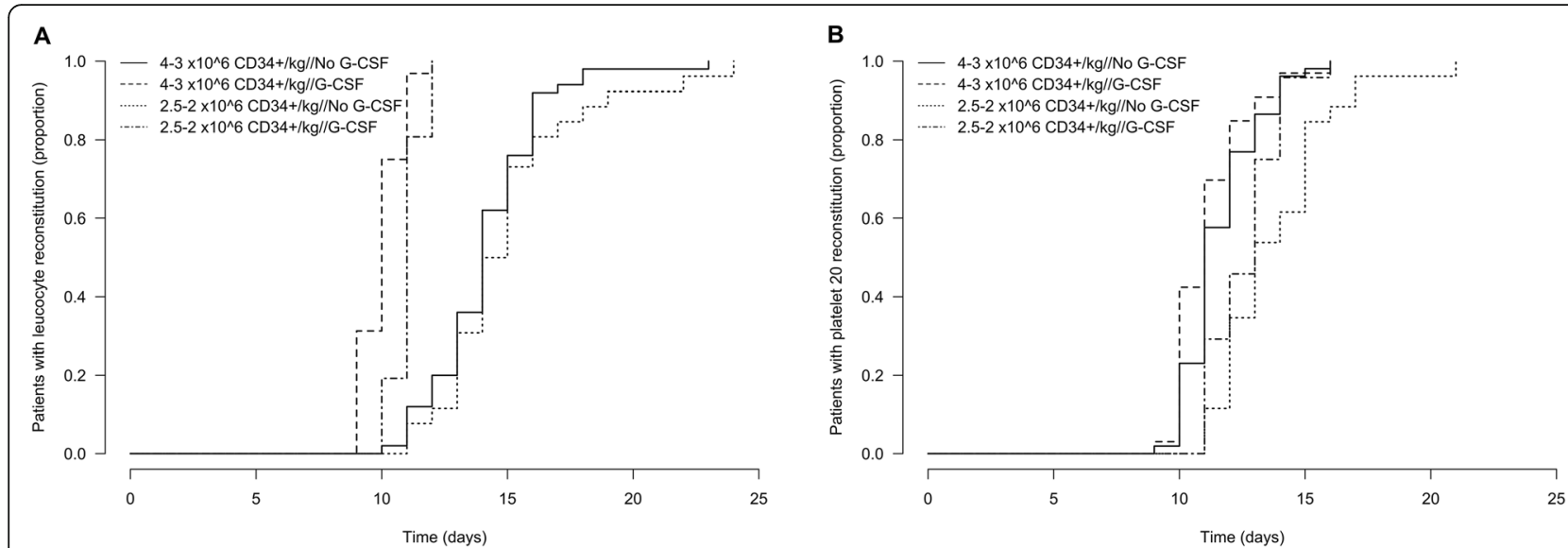

Fig. 2 Hematopoietic reconstitution after HD/ASCT by the number of reinfused CD34+ cells and by G-CSF support status. The relative number of patients with leukocyte recovery $\geq 1.0 \times 10^{9} / \mathrm{L}$ (a) and platelet recovery $\geq 20 \times 10^{9} / \mathrm{L}$ (b) is shown. The results are grouped according to the number of reinfused CD34+ cells (3-4 versus $2-2.5 \times 10^{6} \mathrm{CD} 34+$ cells $/ \mathrm{kg}$ bw) and G-CSF support status

In the multivariate analysis, neither age at ASCT nor remission status pre-ASCT affected the duration of hematopoietic reconstitution. However, the number of reinfused CD34+ cells significantly influenced the duration until hematopoietic recovery. A low number of reinfused CD34+ cells at ASCT was associated with significantly prolonged time until leukocyte reconstitution $\geq 1.0 \times 10^{9} / \mathrm{L}(p=0.010)$ and platelet recovery $\geq 20 \times 10^{9} / \mathrm{L} \quad(<0.001)$ and $\geq 50 \times 10^{9} / \mathrm{L} \quad(p=$ $0.003)$. As indicated by the univariate analysis, G-CSF support after ASCT significantly accelerated leukocyte reconstitution $(p<0.001)$ but not platelet reconstitution. The results of the multivariate analysis including the hazard ratio (HR) and 95\% confidence interval $\left(\mathrm{Cl}_{95 \%}\right)$ are given in Table 4.

No severe adverse events were observed during or after the considered HD/ASCT in the analyzed cohort.

\section{Discussion}

We retrospectively analyzed the short-term hematopoietic reconstitution in MM patients who received a low-dose PBSC graft after HD chemotherapy with melphalan.

A small cohort of MM patients $(n=9)$ received a very low $\left(<2.0 \times 10^{6} / \mathrm{kg}\right.$ bw) number of CD34+ cells after HD chemotherapy. These numbers might be an insufficient PBSC graft, as defined by the current national guidelines and international agreements $[14,30]$. However, despite the low CD34+ cell count of the transplant all of the patients in group 3 reached hematopoietic reconstitution. Although not assessable by comparative statistics due to low patient numbers, the median time until leukocyte recovery $\geq 1.0 \times 10^{9} / \mathrm{L}$ (12 days) and platelet recovery $\geq 20 \times 10^{9} / \mathrm{L}$ (13 days) in patients who received low numbers of CD34+ cells was similar or even identical to that of patients who received PBSC grafts with high numbers

Table 4 Hematopoietic reconstitution - multivariate analysis

\begin{tabular}{|c|c|c|c|c|c|c|c|c|}
\hline Parameter & $\begin{array}{l}\text { Leukocyte reconstitutio } \\
\left(\geq 1.0 \times 10^{9} / \mathrm{L}\right)\end{array}$ & & Aplasia & & $\begin{array}{l}\text { Platelet reconstitutio } \\
\left(\geq 20 \times 10^{9} / \mathrm{L}\right)\end{array}$ & & $\begin{array}{l}\text { Platelet reconstitutio } \\
\left(\geq 50 \times 10^{9} / \mathrm{L}\right)\end{array}$ & \\
\hline \multirow[t]{2}{*}{$\mathrm{n}$ analyzed } & 130 & & 103 & & 131 & & 76 & \\
\hline & $\mathrm{HR}\left(\mathrm{Cl}_{95}\right)$ & $P$ value & $\mathrm{HR}\left(\mathrm{Cl}_{95}\right)$ & $P$ value & $\mathrm{HR}\left(\mathrm{Cl}_{95}\right)$ & $P$ value & $\mathrm{HR}\left(\mathrm{Cl}_{95}\right)$ & $P$ value \\
\hline $\begin{array}{l}\text { Age at } A B S C T \text { ( } \leq 60 \text { vs. } \\
>60 \text { years) }\end{array}$ & $1.038(0.730-1.476)$ & 0.837 & $1.101(0.725-1.669)$ & 0.652 & $1.086(0.762-1.547)$ & 0.649 & 0.841 (0.529-1.336) & 0.463 \\
\hline $\begin{array}{l}\text { Remission pre } A B S C T \\
\text { (CR/nCR/VGPR vs. PR/ } \\
\text { MR/SD/PD) }\end{array}$ & $0.989(0.681-1.436)$ & 0.952 & $1.129(0.735-1.734)$ & 0.581 & $1.098(0.755-1.598)$ & 0.625 & 1.060 (0.650-1.729) & 0.815 \\
\hline $\begin{array}{l}\text { G-CSF support } \\
\text { (no vs. yes) }\end{array}$ & $16.742(8.514-32.923)$ & $<0.001$ & $9.634(5.425-17.107)$ & $<0.001$ & 1.365 (0.951-1.958) & 0.091 & $1.084(0.655-1.794)$ & 0.753 \\
\hline $\begin{array}{l}\text { CD34+ cells/kg bw } \\
\text { transplanted }(3-4 \text { vs. } \\
\left.2-2.5 \times 10^{6}\right)\end{array}$ & $0.607(0.416-0.885)$ & 0.010 & $0.573(0.375-0.875)$ & 0.010 & $0.438(0.299-0.642)$ & $<0.001$ & $0.442(0.258-0.755)$ & 0.003 \\
\hline
\end{tabular}

ASCT autologous blood stem cell transplantation; $C l$ confidence interval; $C R$ complete remission; $H R$ hazard ratio; G-CSF granulocyte-colony stimulating factor; $M R$ minimal response; $n C R$ near complete remission; $P D$ progressive disease; $P R$ partial remission; $S D$ stable disease; $V G P R$ very good partial remission; vs., versus 
of CD34+ cells. This is in line with the results of earlier studies that demonstrated successful hematopoietic reconstitution in MM patients who received 1.0-2.0 $\times 10^{6}$ CD34+ cells $/ \mathrm{kg}$ as autologous grafts after HD therapy $[31,32]$. Nevertheless these and further studies also demonstrated that the use of high CD34+ cell doses reduces the time until hematopoietic recovery and lowers the risk of graft failure [33]. An analysis of engraftment kinetics after myeloablative chemotherapy additionally showed a clear dose-response relationship between the number of CD34+ cells infused and neutrophil and platelet engraftment. Although a minimal threshold CD34+ cell dose could not be defined, $\geq 5.0 \times 10^{6} \mathrm{CD} 34+$ cells $/ \mathrm{kg}$ appeared to be optimal [34]. Furthermore in allogeneic $\mathrm{T}$ cell-depleted bone marrow transplants it has been reported that CD34+ cell dose was the only variable significantly associated with treatment-related mortality, primarily due to infections and cytopenia and therefore higher CD34+ cell doses may improve outcome in engrafting [35].

All MM patients who received low-dose $\left(2-2.5 \times 10^{6}\right.$ CD34+ cells $/ \mathrm{kg}$ bw) PBSC grafts in this analysis also showed successful hematopoietic recovery after HD melphalan treatment. Due to the large number of evaluated patients, the cohort was accessible to comparative statistics. Therefore, MM patients who received $3-4 \times 10^{6}$ $\mathrm{CD} 34+$ cells $/ \mathrm{kg}$ bw at ASCT were chosen as the comparator group. As previously reported, this number represents the median reference value of reinfused CD34+ cells at our institution [20,21]. Both cohorts had similar age but not sex distributions. Importantly, the type of induction treatment and mobilization therapy was similar in both groups, and no statistically significant differences were identified with regard to remission status prior to ASCT. Therefore, the comparison between groups is based on highly homogeneous cohorts, which, in addition to relatively high case numbers, represents a major strength of the current analysis.

The time to leukocyte, neutrophil and platelet recovery after HD/ASCT treatment observed in patients who received $3-4 \times 10^{6} \mathrm{CD} 34+$ cells $/ \mathrm{kg}$ bw at ASCT was similar to that previously described in MM patients. In particular, Gerzt et al. reported a median 15 days until neutrophil and platelet recovery $\geq 50 \times 10^{9} / \mathrm{L}$, which is in line with our findings [36].

As revealed by multivariate analysis, reinfusion of lower numbers of CD34+ cells (2-2.5 compared to 3$4 \times 10^{6} \mathrm{CD} 34+$ cells $/ \mathrm{kg}$ bw) was associated with significantly prolonged time to leukocyte recovery $\geq 1.0 \times 10^{9} / \mathrm{L}$ and platelet recovery $\geq 20 \times 10^{9} / \mathrm{L}$ and $\geq 50 \times 10^{9} / \mathrm{L}$. This is in line with the findings of previous reports that emphasized the positive correlation between the CD34+ cell dose and time to hematopoietic reconstitution [30, 37, 38]. Remarkably a further study showed that patients who received lower stem cell doses had an increased risk of $>3$ days of absolute neutropenia, compared to patients who received higher stem cell infusions, while at a median follow-up of 51 months, there was no difference in survival between patients with absolute neutropenia $>3$ days versus patients with absolute neutropenia for $\leq 3$ days [39]. On the other hand, it was reported that for older MM patients undergoing HD chemotherapy and ASCT infusion of higher stem cell doses did not yield a reduction in symptom burden or engraftment time in the first weeks after ASCT [40]. Also in accordance to this study multiple, fractionated stem cell infusions (days $0,+2,+4,+6$ ) following HD melphalan did not enhance engraftment kinetics or significantly alter MM patients' clinical course following ASCT [41].

G-CSF support after HD/ASCT treatment significantly shortened the time until leukocyte recovery $\geq 1.0 \times 10^{9} / \mathrm{L}$ but not until platelet recovery. These findings are consistent with previous studies, demonstrating that leukocyte and neutrophil engraftment after autologous progenitor cell transplantation can be accelerated by GCSF support [42-44]. As reported by several studies a single dose of pegfilgrastim is a safe and efficacious alternative to daily injections of filgrastim while patients who received pegfilgrastim showed faster engraftment, lower incidence of febrile neutropenia and a shorter hospitalization [42, 45].

As demonstrated by multivariate analysis, G-CSF support accelerates leukocyte engraftment to a much higher extent than a large reinfusion dose of CD34+ cells (HR 16.742 versus 0.607$)$. To the best of our knowledge, this is the first analysis to evaluate the mutual effect of GCSF administration and CD34+ cell dose on hematopoietic recovery after ASCT.

No severe adverse events were observed during or after the considered HD/ASCT in the analyzed cohort of all $148 \mathrm{MM}$ patients. Of note, during the analysis period we recorded one heavily pretreated 60-year-old female patient who presented with a severe adverse event (Pneumocystis jiroveci pneumonia) after a second HD/ ASCT receiving a low-dose PBSC graft $\left(2.15 \times 10^{6}\right.$ CD34+ cells/kg bw). However, this patient did not meet the inclusion criteria of the current analysis (not first HD/ASCT) and was therefore not evaluated in the study cohort. Remarkably in contrast to that finding, none of the intensely pretreated patients in group 3 presented with a severe adverse event (no severe infections or transfer to intensive care unit was reported) after autologous transplant of a very low PBSC graft.

So far there is no reported clinical experience in the reinfusion of PBSC grafts below the minimum of $2.0 \times$ $10^{6} \mathrm{CD} 34+$ cells/kg bw defined by international guidelines. Yet there are many factors, such as higher age of MM patients, prior extensive chemotherapy or radiation 
therapy, which are associated with poor PBSC mobilization. Triplet regimens that include the immunomodulatory agent lenalidomide have emerged as standard-of-care induction therapy in transplant-eligible patients with MM. However, lenalidomide has been reported to have an adverse effect on PBSC collection [46-48]. A correlation between the length of lenalidomide therapy and decrease in PBSC yield has been reported by different groups. Up to four cycles of lenalidomide exposure may have minimal negative impact on PBSC collection and Plerixafor may overcome these negative effects $[49,50]$. Nevertheless, it may be challenging to achieve the target PBSC yield after lenalidomide-containing regimens and it may result in low-dose grafts with CD34+ cell doses $<2.0 \times 10^{6} / \mathrm{kg}$ bw. Reporting the few available patients, we aimed to exemplarily demonstrate an adequate engraftment of PBSC grafts with $\mathrm{CD} 34+$ cell count below the internationally accepted threshold of $2.0 \times 10^{6} / \mathrm{kg}$ bw and therefore to encourage other centers to perform ASCTs with very low dose PBSC grafts. This is particularly of outstanding importance in a clinical setting when a HD chemotherapy and ASCT represent a therapeutic option but an additional PBSC collection is not feasible.

\section{Conclusion}

In conclusion, our study demonstrates that quantitative and timely sufficient hematopoietic reconstitution is achievable upon reinfusion of low-dose PBSC grafts after HD therapy in MM patients. Further evaluation is required to confirm adequate hematopoietic engraftment in more MM patients who receive very low dose PBSC grafts with $<2.0 \times 10^{6} \mathrm{CD} 34+$ cells $/ \mathrm{kg}$ bw after $\mathrm{HD}$ chemotherapy. While the impact of the CD34+ cell dose is significant but clinically marginal, G-CSF support substantially accelerates the time until leukocyte recovery.

\footnotetext{
Abbreviations

ASCT: Autologous blood stem cell transplantation; bw: Body weight; CAD: Cyclophosphamide, doxorubicin, dexamethasone; Cl: Confidence interval; CR: complete remission; DMSO: Cryosure-D dimethyl sulfoxide; GCSF: Granulocyte-colony-stimulating factor; HD: High-dose; HR: Hazard ratio; ISS: International Staging System; L: Liter; LP: Leukapheresis; MM: Multiple myeloma; NC: Nucleated cell; nCR: Near complete remission; PBSC: Peripheral blood stem cell; p.o.: Per os; PR: Partial remission; VCD: Bortezomib, cyclophosphamide, dexamethasone; VGPR: Very good partial remission; VRD: Bortezomib, lenalidomide, dexamethasone
}

\section{Acknowledgments \\ None.}

\section{Consent for publcation}

Not applicable.

\section{Authors' contributions}

SSa and KK designed the study, acquired, analysed and interpreted the data and drafted the manuscript. TB, KK and MK performed biostatistics. SSa, PP, AS, MC, KJ, PW, CMT and KK were involved in patient selection as well as clinical decision making and contributed data for patient characteristics and/ or transplantation parameters. All authors revised and approved the submitted manuscript.

\section{Funding}

none.

\section{Availability of data and materials}

The datasets generated and/or analyzed during the current study are not publicly available due to current data protection directive but are available from the corresponding author on reasonable request within 6 months after publication of the manuscript.

\section{Ethics approval and consent to participate}

The study was performed in accordance with the Declaration of Helsinki and approved by the Institutional Review Board (Ethic's committee of the University of Heidelberg, S337/2009, S096/2017). Written informed consent for study participation was obtained from all patients.

\section{Competing interests}

The first author and all coauthors confirm that there are no potential conflicts of interest to disclose, except the following: Sandra Sauer: travel grants or honoraria for presentations for Celgene, BMS, Janssen, Takeda and Amgen. Patrick Wuchter: served on advisory boards for Sanofi. Carsten Müller-Tidow: research support and support for clinical trials from multiple pharmaceutical companies. Katharina Kriegsmann: research support from BMS, Celgene, Sanofi, Morphosys.

\section{Author details}

${ }^{1}$ Department of Hematology, Oncology and Rheumatology, Heidelberg University, Im Neuenheimer Feld 410, 69120 Heidelberg, Germany. ${ }^{2}$ Stem Cell Laboratory, IKTZ Heidelberg GmbH, Heidelberg, Germany. ${ }^{3}$ Institute of Pathology, Heidelberg University, Heidelberg, Germany. ${ }^{4}$ Institute of Medical Biometry and Informatics, Heidelberg University, Heidelberg, Germany. ${ }^{5}$ Institute of Transfusion Medicine and Immunology, Medical Faculty Mannheim, Heidelberg University, German Red Cross Blood Service Baden-Württemberg - Hessen, Mannheim, Germany.

Received: 8 August 2019 Accepted: 15 April 2020

Published online: 25 April 2020

\section{References}

1. Hubel K, de la Rubia J, Azar N, Corradini P. Current status of haematopoietic autologous stem cell transplantation in lymphoid malignancies: a European perspective. Eur J Haematol. 2015;94:12-22.

2. Chute JP. Autologous stem cell transplantation for multiple myeloma: underutilized but highly effective. J Natl Cancer Inst. 2019;111(1):7-8.

3. Attal M, Harousseau JL, Stoppa AM, et al. A prospective, randomized trial of autologous bone marrow transplantation and chemotherapy in multiple myeloma. Intergroupe Francais du Myelome. N Engl J Med. 1996;335:91-7.

4. Child JA, Morgan GJ, Davies FE, et al. High-dose chemotherapy with hematopoietic stem-cell rescue for multiple myeloma. N Engl J Med. 2003; 348:1875-83.

5. Regelink JC, van Roessel CH, van Galen KP, Ossenkoppele GJ, Huijgens PC, Zweegman S. Long-term follow-up of tandem autologous stem-cell transplantation in multiple myeloma. J Clin Oncol. 2010;28:e741-3 author reply $\mathrm{e} 744-745$.

6. Attal M, Harousseau JL, Facon T, et al. Single versus double autologous stem-cell transplantation for multiple myeloma. N Engl J Med. 2003;349: 2495-502.

7. Auner HW, Szydlo R, Rone A, et al. Salvage autologous stem cell transplantation for multiple myeloma relapsing or progressing after up-front autologous transplantation. Leukemia Lymphoma. 2013;54:2200-4.

8. Michaelis LC, Saad A, Zhong X, et al. Salvage second hematopoietic cell transplantation in myeloma. Biology Blood Marrow Transpl. 2013;19:760-6.

9. Lemieux E, Hulin C, Caillot D, et al. Autologous stem cell transplantation: an effective salvage therapy in multiple myeloma. Biology Blood Marrow Transpl. 2013;19:445-9.

10. Gratwohl A, Baldomero H, Passweg J. Hematopoietic stem cell transplantation activity in Europe. Curr Opin Hematol. 2013;20:485-93. 
11. Passweg JR, Baldomero H, Peters C, et al. Hematopoietic SCT in Europe: data and trends in 2012 with special consideration of pediatric transplantation. Bone Marrow Transplant. 2014;49:744-50.

12. Chen SH, Wang TF, Yang KL. Hematopoietic stem cell donation. Int J Hematol. 2013;97:446-55.

13. Huijgens PC, Dekker-Van Roessel HM, Jonkhoff AR, et al. High-dose melphalan with G-CSF-stimulated whole blood rescue followed by stem cell harvesting and busulphan/cyclophosphamide with autologous stem cell transplantation in multiple myeloma. Bone Marrow Transplant. 2001;27:925-31.

14. KM HK, Kröger N, Müller L, Worel N, Wuchter $P$, Jarisch A. Leitlinien zur autologen Stammzelltransplantation: Stammzellquelle und Mobilisierung. In: Blutstammzelltransplantation DAfK-u, ed; 2018.

15. Mohty M, Hubel K, Kroger N, et al. Autologous haematopoietic stem cell mobilisation in multiple myeloma and lymphoma patients: a position statement from the European Group for Blood and Marrow Transplantation. Bone Marrow Transplant. 2014;49:865-72.

16. Waterman J, Rybicki L, Bolwell B, et al. Fludarabine as a risk factor for poor stem cell harvest, treatment-related MDS and AML in follicular lymphoma patients after autologous hematopoietic cell transplantation. Bone Marrow Transplant. 2012:47:488-93.

17. Perseghin $\mathrm{P}$, Terruzzi $\mathrm{E}$, Dassi M, et al. Management of poor peripheral blood stem cell mobilization: incidence, predictive factors, alternative strategies and outcome. A retrospective analysis on 2177 patients from three major Italian institutions. Transfusion Apheresis Science. 2009;41:33-7.

18. Wuchter P, Ran D, Bruckner T, et al. Poor mobilization of hematopoietic stem cells-definitions, incidence, risk factors, and impact on outcome of autologous transplantation. Biol Blood Marrow Transplan. 2010;16:490-9.

19. Han $X, M a L$, Zhao $L$, et al. Predictive factors for inadequate stem cell mobilization in Chinese patients with $\mathrm{NHL}$ and $\mathrm{HL}$ : 14-year experience of a single-center study. J Clin Apher. 2012;27:64-74.

20. Lisenko K, Sauer S, Bruckner T, et al. High-dose chemotherapy and autologous stem cell transplantation of patients with multiple myeloma in an outpatient setting. BMC Cancer. 2017;17:151.

21. Lisenko K, Pavel P, Kriegsmann M, et al. Storage duration of autologous stem cell preparations has no impact on hematopoietic recovery after transplantation. Biol Blood Marrow Transplant. 2017;23:684-90.

22. Rajkumar SV. Updated diagnostic criteria and staging system for multiple myeloma. Am Soc Clin Oncol Educ Book. 2016:35:e418-23.

23. Kumar S, Paiva B, Anderson KC, et al. International myeloma working group consensus criteria for response and minimal residual disease assessment in multiple myeloma. Lancet Oncol. 2016;17:e328-46.

24. Hundemer $M$, Engelhardt $M$, Bruckner $T$, et al. Rescue stem cell mobilization with plerixafor economizes leukapheresis in patients with multiple myeloma. J Clin Apher. 2014;29:299-304.

25. Bundesaerztekammer. Richtlinien zur Gewinnung von Blut und Blutbestandteilen und zur Anwendung von Blutprodukten (Hämotherapie) - Zweite Richtlinienanpassung 20102010

26. Bundesaerztekammer. Richtlinie zur Herstellung und Anwendung von hämatopoetischen Stammzellzubereitungen 2014

27. DGTI, DGHO, GPOH. Gemeinsame Stellungnahme der Fachgesellschaften DGTI, DGHO und GPOH zu Genehmigungsverfahren von Stammzellzubereitungen 2009.

28. Sutherland DR, Anderson L, Keeney M, Nayar R, Chin-Yee I. The ISHAGE guidelines for CD34+ cell determination by flow cytometry. International Society of Hematotherapy and Graft Engineering. J Hematother. 1996;5:213-26.

29. Schmitt T, Goldschmidt H, Neben K, et al. Aprepitant, granisetron, and dexamethasone for prevention of chemotherapy-induced nausea and vomiting after high-dose melphalan in autologous transplantation for multiple myeloma: results of a randomized, placebo-controlled phase III trial. J Clin Oncol. 2014:32:3413-20.

30. Jillella AP, Ustun C. What is the optimum number of CD34+ peripheral blood stem cells for an autologous transplant? Stem Cells Dev. 2004;13:598-606.

31. Schiller G, Vescio R, Freytes C, et al. Transplantation of CD34+ peripheral blood progenitor cells after high-dose chemotherapy for patients with advanced multiple myeloma. Blood. 1995;86:390-7.

32. Tricot $\mathrm{G}$, Jagannath $\mathrm{S}$, Vesole $\mathrm{D}$, et al. Peripheral blood stem cell transplants for multiple myeloma: identification of favorable variables for rapid engraftment in 225 patients. Blood. 1995;85:588-96.

33. Shpall EJ, Champlin R, Glaspy JA. Effect of CD34+ peripheral blood progenitor cell dose on hematopoietic recovery. Biol Blood Marrow Transplant. 1998;4:84-92
34. Weaver $\mathrm{CH}$, Hazelton $\mathrm{B}$, Birch $\mathrm{R}$, et al. An analysis of engraftment kinetics as a function of the CD34 content of peripheral blood progenitor cell collections in 692 patients after the administration of myeloablative chemotherapy. Blood. 1995;86:3961-9.

35. Mavroudis D, Read E, Cottler-Fox M, et al. CD34+ cell dose predicts survival, posttransplant morbidity, and rate of hematologic recovery after allogeneic marrow transplants for hematologic malignancies. Blood. 1996;88:3223-9.

36. Gertz MA, Dingli D. How we manage autologous stem cell transplantation for patients with multiple myeloma. Blood. 2014;124:882-90.

37. Nath K, Boles R, McCutchan A, Vangaveti V, Birchley A, Irving I. The relationship between $\mathrm{CD} 34+$ stem cell dose and time to neutrophil recovery in autologous haematopoietic stem cell recipients-a single Centre experience. Transfus Apher Sci. 2018;57:532-6.

38. Fiala MA, Bhamidipati PK, Wang S, et al. The impact of CD34+ cell dose and comorbidities on engraftment following autologous hematopoietic stem cell transplantation. ASCT. 2014;32:7046.

39. Bachier-Rodriguez L, Shah GL, Knezevic A, et al. Engraftment kinetics after high-dose Melphalan autologous stem cell transplant in patients with multiple myeloma. BBMT. 2018:24:144

40. Shah N, Shi Q, Williams LA, et al. Higher stem cell dose infusion after intensive chemotherapy does not improve symptom burden in older patients with multiple myeloma and amyloidosis. Biol Blood Marrow Transplant. 2016;22:226-31.

41. Landau $H$, Wood $K$, Chung DJ, et al. Fractionated stem cell infusions for patients with plasma cell myeloma undergoing autologous hematopoietic cell transplantation. Leuk Lymphoma. 2016;57:1781-5.

42. Singh AD, Parmar S, Patel K, et al. Granulocyte Colony-stimulating factor use after autologous peripheral blood stem cell transplantation: comparison of two practices. Biol Blood Marrow Transplant. 2018;24:288-93.

43. Al Sabty F, Mistrik M, Hrubiko M, Bojtárová E, Martinka J, Batorova A. Optimal Use of Granulocyte Colony Stimulating Factor (G-CSF) after Autologous Hematopoietic Stem Cell Transplantation, vol. 124; 2014. p. 2519.

44. Cottini F, Sborov D, Cho YK, et al. G-CSF Starting Day +1 after Autologous Transplant Is Safer Than Day +5 or Day +7 in Patients with Multiple Myeloma. 2016;128:5790-0.

45. Mathew S, Adel N, Rice RD, et al. Retrospective comparison of the effects of filgrastim and pegfilgrastim on the pace of engraftment in auto-SCT patients. Bone Marrow Transplant. 2010;45:1522-7.

46. Popat U, Saliba R, Thandi R, et al. Impairment of filgrastim-induced stem cell mobilization after prior lenalidomide in patients with multiple myeloma. Biol Blood Marrow Transplant. 2009;15:718-23.

47. Mazumder A, Kaufman J, Niesvizky R, Lonial S, Vesole D, Jagannath S. Effect of lenalidomide therapy on mobilization of peripheral blood stem cells in previously untreated multiple myeloma patients. Leukemia. 2008;22:1280-1 author reply 1281-1282.

48. Kumar S, Dispenzieri A, Lacy MQ, et al. Impact of lenalidomide therapy on stem cell mobilization and engraftment post-peripheral blood stem cell transplantation in patients with newly diagnosed myeloma. Leukemia. 2007; 21:2035-42.

49. Dosani T, Covut F, Pinto R, et al. Impact of lenalidomide on collected hematopoietic myeloid and erythroid progenitors: peripheral stem cell collection may not be affected. Leuk Lymphoma. 2019;60:2199-206.

50. Bhutani D, Zonder J, Valent J, et al. Evaluating the effects of lenalidomide induction therapy on peripheral stem cells collection in patients undergoing autologous stem cell transplant for multiple myeloma. Support Care Cancer. 2013;21:2437-42.

\section{Publisher's Note}

Springer Nature remains neutral with regard to jurisdictional claims in published maps and institutional affiliations. 